\title{
Border crimes, extraterritorial jurisdiction, and the racialization of sovereignty in the Ethiopia-British Somaliland borderlands during the 1920s
}

\author{
Daniel K. Thompson
}

This article examines how European extraterritorial jurisdiction shaped identity politics in early twentieth-century eastern Ethiopia. While the Ethiopian Empire maintained its formal independence from European colonialism, intensifying global markets and British, French and Italian expansion into surrounding lands brought numerous European officials and merchants to Ethiopia. Motivated in part by understandings of racial and civilizational hierarchies, European governments worked to protect their nationals from the 'uncivilized' or 'barbarous' rule of dark-skinned Ethiopians. ${ }^{1}$ The politics of extraterritorial jurisdiction converged around the Franco-Ethiopia Treaty of 10 January 1908, known as the Klobukowski Treaty. The Treaty's Article 7 established the legal basis for protecting European nationals and protégés from exclusive Ethiopian prosecution. ${ }^{2}$ To Ethiopian rulers' surprise, in a 1925 court case, British officials invoked the Treaty to protect not Europeans or other foreigners, but Somalis who lived in Ethiopia's territory but whose subjecthood remained contested between Ethiopia and the British Somaliland Protectorate (hereafter British Somaliland, or Somaliland). In part by mobilizing international law on extraterritorial jurisdiction, I argue, assertions about Ethiopian law's inapplicability to Somalis during the 1920s worked to racialize Ethiopian sovereignty and delegitimize its application to Somalis inhabiting eastern Ethiopia.

As competition between the Ethiopian and British empires to organize trade and taxation along the Ethiopia-British Somaliland border intensified into the 1920s, the ordering concepts and structures of global politics were shifting. After World War One, concepts of nationality met European ideas about exclusive territoriality; the term 'nation state' entered English-language usage around 1918 (Kelly and Kaplan 2001: 2). Woodrow Wilson's Fourteen Points connected sovereignty to 'the interests of the populations concerned' rather than imperial interests. ${ }^{3}$ The League of Nations Covenant (1919) defined a new global politics as

\footnotetext{
Daniel K. Thompson is Assistant Professor of Anthropology at the University of California, Merced. His research examines state building, contraband trade and urban economic development in eastern Ethiopia. Email: daniel.thompson@ucmerced.edu

${ }^{1}$ See, for example, Foreign Office (FO) 401/8, Inclosure [sic] in No. 137. Unless otherwise specified, archival citations are from the UK National Archives.

${ }^{2}$ The Treaty established the rights of French nationals and protected persons to trial by a mixed court comprised of Ethiopian officials and French consular agents. However, it was negotiated in recognition that these rights would be extended to subjects of other European powers whose treaties with Ethiopia included 'most-favoured-nation' clauses granting them equal privileges.

${ }^{3}$ The Avalon Project, 'President Woodrow Wilson's Fourteen Points' < http://avalon.law.yale.edu/ 20th_century/wilson14.asp>, accessed 18 May 2020.
} 
relations among 'nations' and 'organized peoples'. ${ }^{4}$ Concepts of civilizational hierarchies structured parallel efforts to territorialize identities in African colonies. Lord Lugard's The Dual Mandate (1922) exemplified European imperialism's dual logics: the distinction between white colonizers and black colonized and the division of Africans into 'native' ethnic categories through indirect rule (MacArthur 2016; Mamdani 1996). Pierre (2013: 34) argues that African identities were enforced through a binary in which 'tribal Africans were uncivilized and governed by custom while Europeans were of civilized nations and governed by law' (cf. Mills 1999: 20). As mobilized by Britons, Somalis and Ethiopians amidst legal disputes during the 1920s, however, notions of tribes, races and nations (and their relations to law and custom) could articulate flexibly to establish or disavow the authority of one group over another in ways that carried international significance, and that were being newly territorialized.

Shifts in the organizing concepts of global governance created scope for Ethiopian empire building. They also brought Eurocentric racial and territorial politics to bear on eastern African conceptions of identity. Long-standing highland Abyssinian organization around emperors claiming Solomonic ancestry met concepts of sovereign territoriality. As a result, '[t]he idea of Ethiopia became anchored for the first time to a fixed geographic space' (Marzagora 2017: 429). The Abyssinian Empire's frontiers had previously fluctuated, defined less by territorial than by social boundaries of Christianity and Abyssinian (or Habesha, predominantly Amhara) culture, distinguished from Muslims to the north and east, Oromos (with their gada socio-religious system) and the more race-like demarcation of darker-skinned shankilla in the lowlands (Donham 1986). Emperor Haile Selassie (writing in the 1930s) described Ethiopia as 'the bastion of Christianity for more than a millennium among the savages and pagans in the arid desert' (Sellassie 1999: 118). Abyssinian rule over surrounding groups dovetailed with European perspectives of Ethiopian highlanders as more 'civilized' and more 'white' than other Africans, views cemented by Emperor Menelik II's 1896 victory over the Italians at Adwa, which secured Ethiopian independence (Marcus 1971).

While European governments officially recognized Ethiopia, persistent efforts to influence the Ethiopian Empire resulted in a 'semicolonial' state: Ethiopian sovereignty was partially subordinated to the authority of better-resourced and more globally influential European powers (Feyissa 2016). The Klobukowski Treaty was one of several legal instruments structuring this subordination and took shape within the framework of European efforts to uphold racial hierarchies (British officials discussed treaty negotiations in terms of 'a policy in the interest of whites as against blacks' ${ }^{5}$ ). The Treaty's Article 7 established that, until Ethiopia's legal system was Europeanized, mixed cases involving European and Ethiopian subjects would be heard by a 'special court' (also called a 'mixed court') in which an Ethiopian judge presided, advised by a European diplomat according to the European party's nationality. A turbulent decade intervened between Menelik signing the Treaty and the establishment of Ethiopia's Special Court in

\footnotetext{
${ }^{4}$ The Avalon Project, 'The Covenant of the League of Nations' < https://avalon.law.yale.edu/ 20th_century/leagcov.asp>, accessed 18 May 2020.

${ }^{5}$ FO 401/10, Inclosure in No. 21.
} 
1922, during the reign of Empress Zewditu (and Ethiopia's regent, Ras Tafari later crowned Emperor Haile Selassie). The timing was important: Ethiopia's 1923 conditional acceptance as a member of the League of Nations solidified its international position as 'both sovereign and less-than-sovereign' (Parfitt 2011: 859). The League's special conditions made Ethiopia's membership contingent on the abolition of slavery and a restriction of arms imports. However, in effect, Ethiopia's international status depended on League members' recognition of its modernization efforts. During the 1920s, court cases therefore carried latent political significance. Unsatisfactory judgments could be cited to evince Ethiopia's legal backwardness.

Feyissa (2016) argues from a legal standpoint that European extraterritorial jurisdiction in Ethiopia was relatively weak. Despite this, I suggest, it forcefully obstructed Ethiopian sovereignty in the Somali-inhabited borderlands. This is in part because legal applications of extraterritoriality enabled Britons and some Somalis to conjoin two racializing logics of 'extraterritorial' status to impede Ethiopian governance over Somalis. The first logic related to Somali pastoralists' status as indigenes who pre-existed Ethiopia's territoriality. Despite the territorial division of the Horn of Africa between British, Ethiopian, French and Italian empires by 1900, imperial powers generally recognized Somalis' rights to maintain pastoralist migrations and (to some extent) trade connections across borders. This gave Somalis scope to manipulate tensions between imperial powers and use flexible political identities to their own advantage (Barnes 2000; 2010; Cassanelli 2010). The logic of Somalis' nativeness was manifest in the 1897 Ethiopia-British Somali Coast Protectorate Frontier Treaty, which recognized Somaliland subjects' rights to access grazing lands in Ethiopia without thereby becoming Ethiopian subjects. ${ }^{6}$

By the 1920s, however, the relative power of Somalis in Ethiopia as well as Kenya (British East Africa before 1920) was being shaped by a second logic associated with British protections afforded Asian 'foreigners'. In Kenya, Isaq Somalis claimed privileges of 'non-native' Asiatic status through the 1919 Somali Exemption Ordinance, asserting their superiority to 'Africans' (Turton 1974; Weitzberg 2017: 38-44). Similarly, when a case of smuggling and Somalis' murder of Ethiopian soldiers came before Addis Ababa's Special Court in 1925 and was forwarded to Ras Tafari's High Court, Britons and Somalis applied the Klobukowski Treaty to Somalis for the first time, effectively asserting their legal equivalence to 'foreign' British-protected merchants in order to exempt the defendants from Ethiopian law. Britons' defence of the Somalis combined the logic of Somalis' status as 'tribal' natives in eastern Ethiopia with a claim that Somalis were effectively foreigners under Ethiopian imperial law. This articulation established new, racialized parameters for eastern Ethiopia's identity politics. In the immediate context, it legitimized tax evasion and 'contraband' trade, disrupting Ethiopian economic regulation. In the longer term, it heightened ethnicity's political relevance. In few regions have identity-related disputes proved to be as bitter as in eastern Ethiopia, where they culminated in the 1977 Ethio-Somali War and in ongoing secessionist undercurrents.

\footnotetext{
${ }^{6}$ For Treaty text and annexes, see Hertslet (1967: 423-31).
} 
In what follows, I analyse the 1925 court case, its background, and its aftermath in the context of related political-legal confrontations involving Britons, Ethiopians and Somalis. Materials are drawn mainly from British archives, but my interpretation took place amidst research on present-day trade around Jigjiga, Ethiopia, in 2017-18. In the first two sections, I describe the case and its relevance to regional identity politics. The third section contextualizes the case within struggles over economic sovereignty. The fourth examines how two racializing logics of extraterritoriality converged to reframe existing disputes about identity and subjecthood. The final substantive section suggests how assertions about racial differences continued to undermine Ethiopian sovereignty in the 1930 s and 1940s.

\section{Somalis' law?}

On 31 July 1925, Talan Sharmarke, Ahmed Harwa and Doordei Samatar stood trial in Addis Ababa for the murder of five Ethiopian soldiers that January near the British Somaliland-Ethiopia boundary. Much of the hearing centred around clarifying what had occurred in Ethiopia's outlying eastern districts as the case worked its way from Jigjiga's local court to the regional mixed court (mejlis) at Harar, to Addis Ababa's Special Court.

Ato Germani, one of the deceased soldier's relatives, testified: 'I only knew I had a relation who died. I was not present, but was summoned to Harrar. I was asked if I would take blood-money. And I said my relation died on duty. I will take no blood-money. But I will kill the man who killed him.'7 Other relatives of victims agreed and sought a death sentence for the Somalis. British sources allege that Ethiopian authorities pressured them to do so. Blood money (mag or diya), a principle of Somali dispute resolution, was deemed inappropriate for these Abyssinians. It seems the accused Somalis pled guilty in the regional courts, assuming that the penalty would be 100 camels per man killed, ${ }^{8}$ a precolonial mag penalty selectively institutionalized by British Somaliland authorities. The penalty was not the assailant's responsibility but the clan's. Plowman, a British consul working in eastern Ethiopia, had even secured a promise from leaders of the defendants' clan, the Gadabursi, to provide camels as payment. He probably expected that this would expedite the case's resolution. From an Ethiopian perspective, it appeared an affirmation of the Somalis' guilt.

The Ethiopian judge turned to Mr Gardiner, counsel for the accused, and asked how the prisoners pled. 'Not guilty,' came the reply. This seemed an about-turn from how the three had pled in Jigjiga's and Harar's courts, so the judge sought to clarify:

\footnotetext{
${ }^{7}$ This and subsequent quotations until the next cited record are from FO 401/19, Enclosure 7 in No. 48. I retain original spellings in all source quotations. Harrar refers to Harar. Archival references to Jigjiga as well as names including Tafari, Harwa and Somali clan names employ inconsistent spelling.

${ }^{8}$ The fine for killing a woman was fifty camels.
} 
Judge:

Samatar:

Gardiner [after consultation with the accused]:

Judge:

Sharmarke:
Did you admit the murder?

I did not admit the murder before anybody.

The accused say that they did not understand. They thought the court was asking if they admitted the crime [in the present hearing, as opposed to their previous confession at Harar]. I explained to them what the court was asking. Will the court now question them again.

You tell me a different story to that of the report of proceedings at Harrar.

We did not commit the murder. At Jigjiga they pressed us to make a confession; the short (Ahmed Harga) one was heavily beaten over the ear and still has pus in it [sic]. At that time we confessed the murder, thinking we would escape worse treatment.

Bullock, a British diplomat observing the case, noted: 'The whole case rests on the alleged confession of Telen Shermarki and Ahmed Harga, both at Jigjiga and Harrar.' These confessions were given under duress and through interpreters. He concluded that 'according to English procedure, the confession of these men should not be considered valid evidence against them'. In the end, the Special Court reached no verdict and the judge forwarded the case to Tafari's High Court.

Why, in 1925, were three Somalis, apprehended for murder in what both British and Ethiopian authorities regarded as the Horn's lawless borderlands, brought to stand trial before Ethiopia's regent himself? Furthermore, why were British diplomats so concerned over a death sentence for people they consistently branded an intransigently violent race - and whom they put to death themselves for similar crimes? Doordei Samatar partly answered this in his testimony before Addis Ababa's Special Court:

Samatar: I am a British subject and spend my time travelling. For eight days I was a prisoner without food, and also in a very bad prison, full of bugs and fleas. Five men were guarding me and they all had big sticks. When I was examined, I said I knew nothing about it. But when a man is hard pressed, he has to admit.

Judge: Before Dejazmatch Imaru [Governor of Harar] what did you say?

Samatar: When we were before Dejazmatch Imaru the interpreter was an Abyssinian.

Samatar's claims raised a combustible issue that had simmered in the region for two decades but came to a head during the 1920s: after dividing their territories, authorities in Ethiopia and Somaliland had not defined the subject status of some borderlands Somalis. The assertion of British subjecthood sought to render Ethiopian court proceedings inapplicable to Somalis ostensibly indigenous to Ethiopia but who claimed British protection and questioned the authority of 'Abyssinian' officials over these Somalis. 
British officials initially defended the Somalis by claiming that Ethiopian law (ethnicized as 'Abyssinian law'9) did not apply to Muslim Somalis. Plowman treated the case as 'a tribal matter to be settled in accordance with precedent by claimant [sic] of blood-money by the tribes concerned', according to a 26 May dispatch. ${ }^{10}$ One precedent cited was Ethiopians' payment of blood money after a 1921 massacre of Somalis at Dire Dawa. When the Special Court judge referred the case to the High Court, however, Tafari defied British pressure and condemned the Somalis to death on 11 November 1925. In the sentence he rejected distinctions between 'Abyssinian law' and 'Somalis' law' (an accurate assessment of Britons' position, even if British written correspondence does not refer to 'Somalis' law'). ${ }^{11}$ His ruling asserted that Ethiopian imperial law applied to Africans within Ethiopia's borders. After Tafari's verdict, however, British officials invoked the Klobukowski Treaty, leveraging international law to protect the Somalis from Ethiopian justice.

The judicial dispute revealed a conjuncture between what can be conceptualized as two logics of extraterritorial jurisdiction as practised in eastern Ethiopia. One exempted 'British Somalis' from Ethiopian law based on their status as 'tribal' Somalis over whom 'Abyssinian' jurisdiction was culturally inappropriate. Before recognizing Ethiopia's eastern border in the 1897 Frontier Treaty, Britons had pledged to protect some Somali clans along with 'territories under their authority and jurisdiction'. ${ }^{12}$ Britons described the subsequent 1897 Treaty as a 'transfer of suzerainty' (Hertslet 1967: 425), a logic envisioning Britons and Abyssinians as foreign colonizers committed to upholding Somali social organization. In the view of Somaliland officials, this gave Britons authority to intervene in eastern Ethiopia to ensure that Somalis' precolonial institutions and territories were protected. This logic undergirded extraterritoriality as a modus vivendi in eastern Ethiopia prior to the case: British officials often relied on Ethiopian judges to settle disputes involving British Somalis through 'customary' penalties such as mag rather than adhering strictly to Ethiopian imperial law. The second logic was recognition of Somalis in Ethiopia as effectively foreign British subjects exempt from Ethiopian law - a recognition that Tafari was loath to give. British correspondence regarding the case evinces these two logics. Somaliland's Assistant Secretary had mentioned 'extraterritorial jurisdiction' early in the case (on $28 \mathrm{March}$ ), and the case was tried through the Special Court system that had recently been created to fulfil the Klobukowski Treaty. Yet, evidently assuming that the case would be quickly settled through blood money, British officials did not formally assert the Klobukowski Treaty's relevance until 16 November, according to written correspondence regarding the case (in FO 401/19, No. 48). As discussed below, even when he did invoke the Treaty, Britain's Consul-General to Ethiopia, C. H. Bentinck, appeared unsure that the Treaty

\footnotetext{
${ }^{9}$ Relaying the trial's early stages from Harar in May 1925, Plowman explicitly contrasted rights to revenge under 'Abyssinian law' with the payment of 'Moslem diya', which Britons would accept on behalf of the defendants. FO 401/19, Enclosure 2 in No. 48.

${ }^{10}$ FO 401/19, Enclosure 3 in No. 48.

${ }^{11}$ FO 401/19, Enclosure 9 in No. 48.

${ }^{12}$ FO 403/313, No. 163.
} 
should be explicitly applied to Somalis. Likewise, Tafari evidently did not anticipate that Britons would apply the Treaty to protect Africans.

The case raised a dilemma for Ethiopian state building: in order to uphold Ethiopia's international obligations as a sovereign nation, Tafari effectively had to revoke sovereignty over some Somalis native to Ethiopian territory. Moreover, as Tafari's verdict recognized, Britons' claims to extraterritorial jurisdiction were mixed with assertions of fundamental identity distinctions. This meant that Ethiopia's capitulation would legitimize Britons' claims that Ethiopian imperial law was irrelevant to certain Somali groups due to what Britons understood as Somalis' racial differences from Abyssinians. To grasp the significance of the case and its challenge to Ethiopian sovereignty, it is important to understand how European racial logics shaped the borderlands' landscape of imperialism.

\section{Race, 'tribe' and governance before 1920}

Conceptions of difference based on race, 'tribe', civilization and nationality frequently blurred in British discourse about eastern Africans. These terms, however, evoked underlying notions of racial types (e.g. 'the Somali', inevitably represented as male) with cultural proclivities. When adventurer Richard Burton termed 'Ise Somalis a 'fierce and turbulent race of republicans' in the 1850 s, his connection of hereditary characteristics to cultural aspects of the Somali 'nation' he mentioned on the same page was typical of contemporary assumptions (Burton 1856: 174). Colonial officials even framed political tensions as inherited proclivities: 'It must be remembered,' wrote Somaliland's Commissioner Manning in 1910, 'that the distrust and dislike of the Somali for the Abyssinian is deeply rooted and hereditary, and dates back to a period anterior to the British occupation of the Somali coast.' ${ }^{13}$

Such racial assertions legitimized British 'protection' of Somalis in the borderlands from Ethiopian jurisdiction but existed in tension with Britain's formal commitments to Somalis and to the Ethiopian Empire. The Somaliland Protectorate had been established through treaties pledging protection to some Somalis (including subdivisions of 'Ise, Gadabursi and Isaq clans) in the 1880s. However, after Ethiopia's 1896 victory at Adwa, the British Home Government accepted a territorial settlement that bisected these groups' lands. The 1897 Treaty established a compromise between Ethiopian territorial ambitions and British efforts to honour their Somali treaties. It guaranteed the right of British-protected Somalis to cross the border with their livestock in order to reach mid-altitude pastures (the Haud) in Ethiopia. The agreement grounded British claims to extraterritorial sovereignty in Somaliland clans' 'traditional' mobility into what was now Ethiopian territory. Ideally, an Isaq, wherever he was, could claim British subjecthood. Ogaden, Jidwaq and other groups were Ethiopian subjects. Both Britons and Ethiopians claimed the Gadabursi and 'Ise. By 1910, in sum, while ideas about Somalis' racial proclivities shaped British approaches to rule, the ethnic category 'Somali' was politically ambivalent. So-called British Somalis' rights in

\footnotetext{
${ }^{13}$ FO 401/14, Enclosure in No. 3.
} 
Ethiopia - and Britons' capacity to assert sovereignty over them - were grounded in logics of precolonial clan organization and territoriality.

This logic of Somalis' racialization as clan members transformed clan functions and reshaped the landscape of imperial intervention. It is relevant not only that colonial governance tended to increase the political potency of clan identity and calcify leadership structures (Kapteijns 2010; Samatar 1989: 44), but also that differences between clans were often understood in racial terms that shaped Britons' approaches to intergroup relations. 'Somalis of different tribes differ so greatly,' wrote Drake-Brockman (1912: 86), 'that one must constantly bear in mind the race or tribe of whom [a European] traveler is speaking.' A 1901 report positioned the 'more law-abiding Gadabursi' as 'perhaps higher in the scale of civilization than the Esa ['Ise]'. ${ }^{14}$ British favouritism towards Isaqs notwithstanding, Gadabursis began early on to find some favour among British Somaliland officials.

Assertions about Somalis' - and specific Somali clans' - proclivities to disorder shaped a precarious convergence of British and Ethiopian interests after the 1897 Treaty. Cooperation between British and Ethiopian authorities in the borderlands focused on eliminating Sayyid Mohamed's anti-colonial war (the Dervish War) and bringing 'orderly' government to Somalis (especially Ogadenis), whom not only Britons but also Ethiopian officials 'clearly regarded ... as a problem' (Carmichael 2001: 167). To some extent, British Somaliland's authorities encouraged the progress of Ethiopian governance over 'their' clans (Barnes 2000: 46-54). Somaliland supplied and advised Ethiopian forces, facilitating Ethiopia's military expansion. Somaliland officials relied on Ethiopian authorities to mediate transborder livestock and trade disputes. From 1897 until the early 1920s, the exercise of British sovereignty over Somalis in Ethiopia was generally negotiated in Harar and Jigjiga based on the 1897 Treaty and without explicit reference to international laws that concerned other European powers.

The British abandoned their administration of Somaliland's interior in 1910, facing mounting security costs during the Dervish War. They returned in 1914 to find that, amidst conflict and famine in the intervening years, administration in Jigjiga had advanced and Ethiopians were exercising more effective authority over Somalis, including British-claimed clans. By the 1910s, Ethiopian authorities were also beginning attempts at legal centralization, in which imperial law extended into peripheral areas but coexisted with regional judicial practice (Carmichael 2001). In the eastern regions governed from the ancient city of Harar, the imperial court held final authority but worked alongside Islamic courts. In this context, the establishment of Ethiopia's Special Court in 1922 was an ostensible advance towards legal 'modernization'. 'Mixed court' branches in Dire Dawa, Harar and Gore fell under the authority of Addis Ababa's Special Court (and with final appeal to Tafari's High Court) (Scholler 1985: 51). These courts applied Ethiopian imperial law in cases with Ethiopian defendants, and defendants' 'national law' in cases with foreign defendants. In practice, mag and other customary penalties continued to be commonly enforced when Somalis appeared in Harar's mixed court (Scholler 1985). This perhaps tacitly validated Britons' assumptions that 'Abyssinian law' was culturally inappropriate for Somalis.

\footnotetext{
${ }^{14} \mathrm{FO} 403 / 313$, Inclosure 1 in No. 56.
} 
Other scholars have referred to the trial of Sharmarke, Harwa and Samatar, for example noting that disputes over extraterritoriality 'first came to a head in 1925, when Tafari sentenced three British Somalis to death for murder' (Edwards 1984: 376). However, works on extraterritorial jurisdiction in Ethiopia (for example, Scholler 1985) have tended to take the logic of British claims (and the category 'British Somalis') as a given rather than observing that the 1925 case was a pivotal moment in the construction of identities amidst a regional power struggle. As discussed in the following section, the case emerged from contests to control taxation and trade in which clan was an important, though unstable, mechanism of imperial control. It was partly due to difficulties in defining clans' subjecthood, co-opting clan structures and enforcing Ethiopian recognition of British-protected status that Britons mobilized other logics of race and nationality to subordinate Ethiopian economic governance to Somaliland's interests.

\section{Disputes over tax, trade and subjecthood}

The crime for which the three Somalis stood trial connected struggles over economic sovereignty in the Ethiopian borderlands to international legal frameworks underpinning capitalism's evolving terrain. With standardized international currency across much of the world by 1900, foreign trade was booming and European powers competed to obtain raw imports and to export manufactured goods. (In the Jigjiga area, Maria Theresa dollars, which predominated in Ethiopia, and British-Indian rupees, which were used in Somaliland, circulated alongside 'amerikani' cotton sheeting used as trade currency.) As was the case elsewhere in Africa, the segregation and control of African societies, legitimated by racial ideologies, facilitated the expansion of European capitalist extraction (Hall 1980; Mills 1999: 25-39). Ethiopia, though formally an exception to Africa's colonization, was hardly exceptional in this regard. The 1906 agreement of the Tripartite Powers (Britain, France and Italy) to uphold Ethiopia's sovereignty and the 1908 Klobukowski Treaty were connected to European governments' efforts to protect railway, banking and European merchant interests (Keefer 1981). Landlocked Ethiopia's trade flowed through European-controlled coastal ports.

Political sovereignty, even if partly subordinate to European interests, gave Ethiopians a degree of economic control that created conflicts with European powers. Import-export taxes were contentious, and as Ethiopian officials consolidated control over border areas in the 1910s, they also attempted to stem some trade circulations. A formal prohibition on dollar imports was in place from 1919 to 1934 . More relevant to the 1925 case was a concurrent prohibition on grain exports. British Somaliland's authorities focused on livestock trade and left agriculture undeveloped until the mid-1920s, leaving the Protectorate dependent on imported grain (Samatar 1989: 53-6). Ethiopian livestock and grain production both supplied Somaliland's economy, but due to Somalis' transborder grazing movements, livestock could not be unambiguously categorized as trade items. Grain, on the other hand, was grown in a fixed place, and thus could be identified as contraband. Grain smuggling therefore created opportunities for Ethiopian officials to assert their authority in a borderlands area subject to British interference. 
The incident for which Sharmarke, Harwa and Samatar stood trial was tied to Somaliland's dependence on imported grain and Ethiopian efforts to prevent exports, as Plowman recorded in March 1925:

A trading caravan of Gadabursi Makahil Dera was arrested by five Abyssinian soldiers near Ibsa for smuggling grain, and was brought to a Jibril Yunis village. The Abyssinians were promised money, and while they were off their guard, were set upon by their captives, bound, taken off into the bush some miles from the village, and there strangled to death with ropes. ${ }^{15}$

Jigjiga's sub-governor (subordinate to Harar's governor) from 1917 to 1920, Tekle-Hawaryat, had incentivized Somalis' grain production (Tekle-Mariam 2006: 354-6). At the same time as Somaliland officials claimed Gadabursis as British subjects and asserted their rights to cross-border mobility and trade, increasing reliance on agriculture grounded many Gadabursi residences and livelihood sources in Ethiopian territory. The Gadabursi became the nexus of a broader issue plaguing borderlands administration: in the context of Somalis' transborder mobility and ambiguity regarding the border's exact location (before its demarcation in 1932-34), who could legitimately impose taxes and trade restrictions, on whom, and where?

The decentralized Ethiopian imperial system historically relied on several conceptually distinct forms of taxation. Somali historians writing of the 1890s, when Abyssinian officials began formalizing administration in the area, voice complaints about the gibir or head tax. While highland agricultural areas had long been subject to such taxes, Somalis, 'who had not previously known taxation, saw the issue as injustice and aggression, and rejected it out of hand' (Galaal 2017: 48, my translation). In the 1890s, Abyssinian taxation was primarily in kind. 'At that time,' writes Ahmed 'Abdi Haybe, 'the people did not have money, so the clans used to pay the gibir in livestock' (Haybe 2017: 28, my translation). British encouragement of livestock exports by 1900 began to increase the penetration of a cash economy into pastoralist areas, although Ethiopian taxes were still often paid in kind or forcibly collected in the form of livestock tribute (Eshete 1994). By 1920, the Gadabursi in particular were 'especially valuable tax-payers - tax which was primarily paid in grain' (Barnes 2000: 108).

At the same time, the growth of trade towns in Ethiopian border areas - partly a result of heightened trade with European powers - increased the significance of trade taxes imposed at customs posts or kella (Garretson 1979). In Ethiopia's eastern borderlands, efforts to impose trade taxes undermined British Somaliland's control over trade networks stretching into Ethiopia. Both taxation through the gibir system and Ethiopian efforts to govern trade were evidently organized through the Somali clan system, co-opting existing mechanisms of kinship-based resource mobilization and trade protection. Clan representatives served as intermediaries in both forms of taxation - and, indeed, head taxes (gibir) and trade taxes are not clearly distinguishable in narrations of everyday economic regulation at Jigjiga. When administration returned to Somaliland's interior in 1914 (after the 1910 British withdrawal), Britons were incensed that

${ }^{15}$ FO 401/19, Enclosure 1 in No. 48. 
Jigjiga's governor Abdullah Taha had imposed a yearly 'tribute' (probably gibir) on clans along the border. He had even employed borderlands clan leaders to work with Ethiopian administrators in Jigjiga, which evidently both justified and facilitated clan-based taxation and trade regulation. While contesting Abdullah Taha's right to tax British-protected Somalis and to recruit them into Ethiopian service, Britons asserted their intention 'to recapture the trade now passing through Jig Jigga for the benefit of our Somaliland protectorate' and declared: 'The Somali would prefer to deal through a British town, where he well knows that he will always meet with just treatment and a small taxation, which he cannot expect to enjoy at the hands of the Abyssinian authorities.' 16

Bias in British records notwithstanding, there are reasons to believe that British rule was, fiscally speaking, more beneficent. Britons could afford to run Somaliland at a deficit to attract cross-border trade even if the Protectorate's inability to support itself provoked criticism in Britain. Somaliland was a piece of a massive empire, a piece that helped secure a corridor for east-west trade via the Suez Canal. Furthermore, expenditures in Somaliland were relatively miniscule even if local revenues were insufficient to cover them. Looking at Somaliland's finances alone suggests a dire picture: expenditure vastly outpaced local revenue collection from about 1905 onwards, proportionally more so than in other African colonies (Figure 1). Yet, even considering eastern Africa - let alone the broader empire and Far East trade - Somaliland's deficit was hardly enough to sink net revenue (Figure 2).

Britons' encouragement of cross-border mobility and trade flows into Somaliland incentivized smuggling and, along with it, potential allegiance to low-tax British authority. Yet despite economic incentives, Somali leaders did not universally reject Ethiopian rule. When British administration resumed after the 1910 withdrawal, Britons discovered that Ugas Robleh, recognized by the Somaliland administration as Gadabursi hereditary chief, was employed by Jigjiga's administration. Somaliland officials replaced him with his son, Daudi, supported by important Gadabursi personages. 'These adjuncts to Daudi were revealingly called "trade agents" by the British, and their appointed task was to attract Gadabursi goods and grain away from Ethiopian jurisdiction into the Protectorate,' says Barnes (2010: 128). Ugas Robleh grew discontent with his position vis-à-vis Ethiopian authority under Gadla-Giyorgis' sub-governorship (around 1920-21) and returned to Somaliland. Meanwhile, Daudi joined the Ethiopians and led Somali police patrols collecting customs dues at the border - and registering Gadabursi sections as Ethiopian subjects.

The 1925 case brought to a head an intensifying conflict over subjecthood and taxation, and raised the prospect of establishing new rationales and precedents for resolving disputes. Consul Plowman, the British representative in Harar and Jigjiga, was absent from the 31 July Special Court trial in Addis Ababa. He arrived that day at Hendesa, a village on the still undemarcated British Somaliland-Ethiopia boundary, to investigate a different case of murder during tax collection. British authorities pushed for a joint resolution of the cases in pursuit of clearer taxation policies regarding British-protected Somalis. On 2 August, Plowman met with Dejazmatch Imaru (Governor of Harar) and

\footnotetext{
${ }^{16}$ FO 401/16, Enclosure 1 in No. 70.
} 


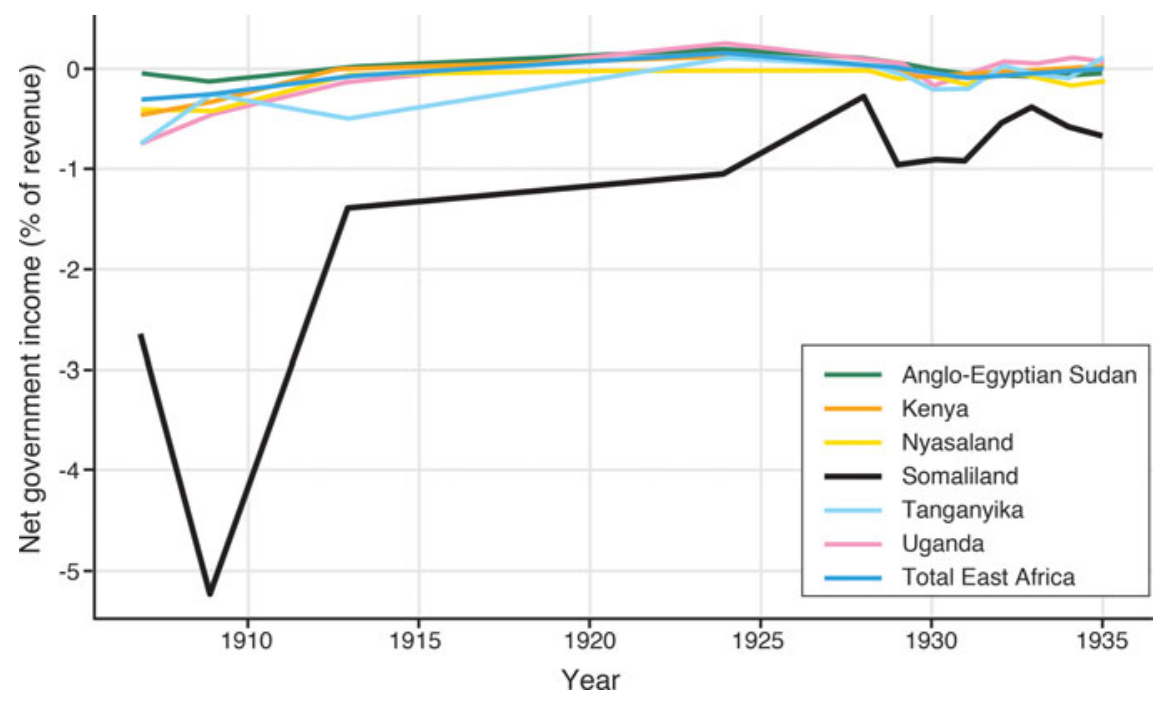

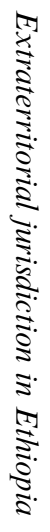

FIGURE 1 Net government income as a percentage of revenue in British Eastern African territories. Source: Data from Frankel (1938). 


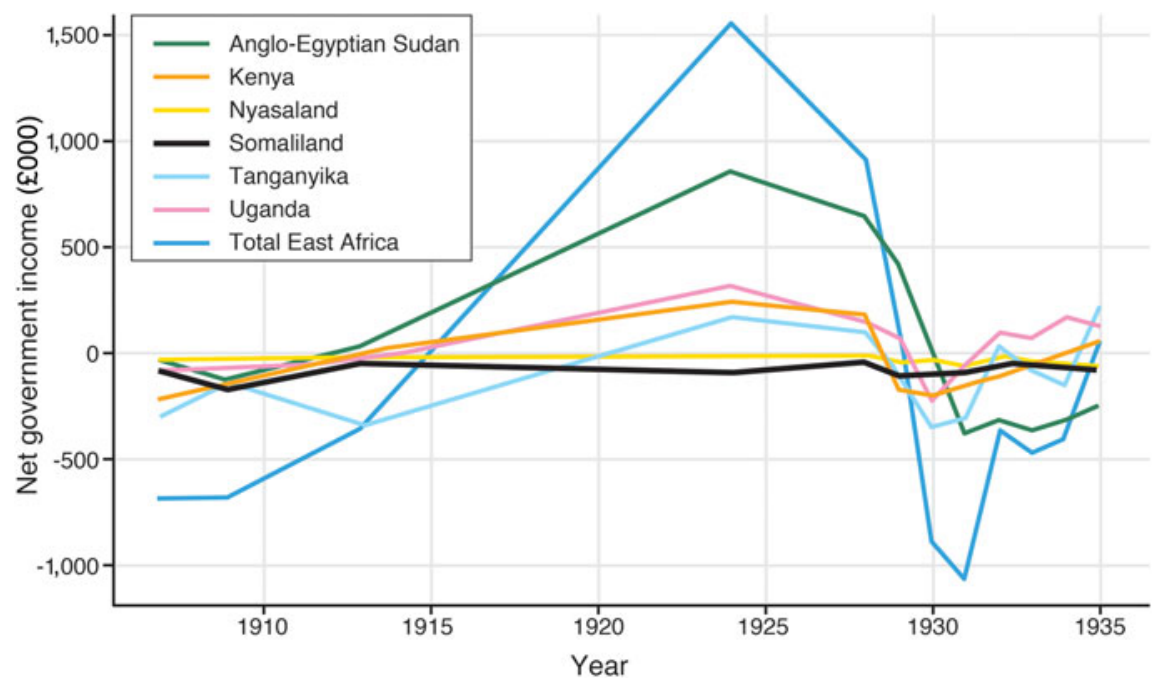

FIGURE 2 Net government income in British Eastern African territories. Source: Data from Frankel (1938). 
Kanyasmatch Gadla-Giyorgis (Sub-Governor of Jigjiga) to hear testimony about a raid two years earlier, in August 1923.

Narratives from both sides in the 1923 Hendesa incident described how a party of Abyssinian and Somali police dispatched from Jigjiga came to Hendesa demanding tax. When the inhabitants refused to pay and drove away their livestock, the police caught three camels. The inhabitants threatened the police, who fled, leaving a Gadabursi man dead. According to British correspondence from Plowman's 1925 visit:

The Abyssinian version was to the effect that the man killed was an Abyssinian Somali who was only at Hendesa on a visit from his village on the other side at Kor Dera, and that the Hendesa village had regularly paid taxes before to the Abyssinian Government. Both statements were denied by the Gadabursi, and were not proved. ${ }^{17}$

No judgment had been reached in 1923 because Britons and Ethiopians focused their claims on Hendesa's territorial location, which could hardly be resolved without demarcating the border on the ground.

In connection with the 1925 Special Court trial, Britons reframed the Hendesa incident from an issue of Hendesa's territoriality into a case of extraterritoriality. In early November 1925 (before Tafari's judgment), Bentinck discussed the Hendesa victim's nationality with Tafari. 'Ras Taffari,' he recorded, 'asked if we could prove by some document that the deceased was really a British subject.' This was not immediately possible. Bentinck said that:

[Dejazmatch Imaru] could not prove that [the victim] was either Abyssinian or British. He had, [Dejazmatch Imaru] said, resided in Abyssinian territory until about a year before his murder, when he had moved to Hendesa. The Dejazmatch was now making enquiries into his parentage in the hopes of thereby establishing his nationality. ${ }^{18}$

Records regarding the 1925 case contain the first mentions I have located of Somalis' 'nationality' in the British Foreign Office documents for Ethiopia contained in the FO 401 series (the earliest mention appears in correspondence from July 1925). Earlier records in the series used the term mainly with reference to Europeans. As the 1925 case progressed, the concepts 'national' and 'nationality' were tentatively applied to 'extraterritorial' British Somalis.

As asserted in the Gadabursi cases, nationality was an ambivalent category. While earlier applications of the term to Europeans imply citizenship, ${ }^{19}$ Somalis were not citizens. British officials often discussed 'British Somalis', but the Home Government clarified this with regard to the 1925 case: Somalis' 'national law' meant 'British-Indian law' - not British law. ${ }^{20}$ Even if 'nationality' did not carry the valence it would decades later amidst Africa's decolonization, assertions about Gadabursis' nationality evoked an ambiguous category that nevertheless could logically connect existing practices of extraterritorial jurisdiction to international frameworks of sovereignty. British authorities had generally translated

\footnotetext{
${ }^{17}$ FO 401/19, Enclosure 1 in No. 82.

${ }^{18}$ FO 401/19, No. 89.

${ }^{19}$ For example, FO 401/10, Nos 32 and 161.

${ }^{20}$ FO 401/19, No. 50.
} 
the Klobukowski Treaty's provision of French consular jurisdiction over French (and, by extension, British) ressortissants ou protégés as 'nationals and protected persons'. ${ }^{21}$ In July 1925, British Consul-General Bentinck wrote to Tafari complaining of the Special Court: '[T]here are far more British cases before the court than those of other nationals. ${ }^{22}$ The court cases he referred to overwhelmingly involved Somalis, Indians and Arabs (see selected cases in Scholler 1985). This flexible deployment of nationality in practice invoked emerging international legal frameworks and, as asserted after Tafari's 11 November verdict, grouped 'tribal' Somalis with foreigners in order to subordinate the application of Ethiopian law to European interests. The next section explicates the two logics of extraterritoriality that converged in the case, showing how the dispute's genesis and Tafari's judgment centred on logics of Somalis' 'tribal' or 'native' status, while its resolution exempted Somalis from prosecution by equating them with 'foreigners'.

\section{Logics of extraterritoriality in practice}

The legal reframing of Gadabursi subjecthood through the ethnicization of Ethiopian imperial law as 'Abyssinian' and claims of Somalis' British nationality established new juridically relevant layers of identity that Somalis could assert, and that Britons could mobilize, to delegitimize Ethiopia's sovereignty. Finergrained accounts of borderlands incentive structures such as Barnes' (2010) study of Gadabursi allegiances are important. However, analysing shifting allegiances is necessary but insufficient for understanding how new configurations of sovereignty shaped persistent divisions that resulted in widespread opposition to Ethiopian rule and outright rebellion after neighbouring Somalia's 1960 independence. A Gadabursi official recently recounted to me how his father, a decorated official serving Haile Selassie during the 1960s and 1970s, resented Ethiopian rule and reaffirmed boundaries between Somalis and Habesha. ${ }^{23}$ I suggest that two logics of extraterritorial status converged in the 1925 case in ways that refracted existing ethnic identities through Euro-colonial racecraft (cf. Pierre 2013).

Somali and Abyssinian (Habesha, including Amhara) ethnic categories were politically relevant in the northern Horn before European colonialism. They were, of course, contingent if entrenched historical constructs rather than (as some Britons claimed) groups based exclusively on heredity. Lij Yasu's reconciliatory efforts towards Somalis during his brief rule as designated Emperor of Ethiopia (1913-16) suggested possibilities of drawing Somalis into a more productive relationship with Ethiopia's Habesha-led power structure (Galaal 2017: 47-52). That his attempts were rejected by highland elites, contributing to his overthrow, reflects the potency of cultural and religious distinctions to both Abyssinians and Somalis. Somali leaders at the time perceived the Amhara as

\footnotetext{
${ }^{21}$ FO 401/13, No. 61.

${ }^{22}$ FO 401/19, Enclosure in No. 32.

${ }^{23}$ Interview, Jigjiga, 7 May 2018.
} 
antagonists. Early twentieth-century poems by Ogaden poets including Qaman Bulhan and Sayyid Mohamed express antipathy towards Amhara, and to nonMuslims generally (Haybe 2017; Sheik- Abdi 1993). Sayyid Mohamed famously asked his co-ethnics: 'If the land is your land, why aren't you its government? If Islam is your religion, why submit to infidel overlords?' (quoted in Sheik- 'Abdi 1993: 211). This suggests imaginaries of Somali unity in the face of colonialism. Nevertheless, the most potent categories of socio-political organization in everyday life along the border by the 1920s were clan - in part because it determined imperial subjecthood - and Islam, a category recognized in legal practice in Harar amidst Ethiopian expansion but that was a categorical 'other' to Tafari's (and other elites') vision of Ethiopia's Christian empire.

Clan or 'tribe' constituted a logic through which British Somaliland officials (and Somalis) claimed some Somalis in Ethiopia as British subjects because of their native status and its corollaries in precolonial clan territories transecting the 1897 boundary. This appears to be the concept of extraterritoriality on which Ras Tafari based his judgment in the 1925 case. What turned Tafari's judgment in this 'tribal' matter into a showdown over Ethiopian sovereignty, however, was a different logic of extraterritoriality: British protection of the large population of (mainly Muslim) Asian merchants who were ostensibly higher in the civilizational hierarchy than African natives and certainly more clearly marked as 'British subjects' due to their foreign identification. This is the category to which Bentinck referred in his July 1925 reference to 'British nationals' in Ethiopian mixed courts. My examination of the case and of the disputes leading to it suggest that a racializing logic of Somalis as 'natives' with transborder territories shaped the conflicts leading to the confrontation, while it was resolved through a different logic: Somalis' legal equivalence to non-Africans.

\section{Tribal (extra)territoriality and subjecthood}

The 1897 Treaty's protection of transborder territoriality enabled a 'de facto construction of nativeness' (Pierre 2013: 12) in which Somalis were members of preexisting 'tribes' (clans) with natural territories. The Treaty's Annex 3 guaranteed the right of 'tribes occupying either side of the line ... to use grazing grounds on the other side, but during their migrations, it is understood that they shall be subject to the jurisdiction of the territorial authority' (Hertslet 1967: 428). What 'subject' meant in this agreement proved contentious. Britons encouraged Somalis to follow Ethiopian rules but rejected the idea that while in Ethiopia they were Ethiopian subjects. 'That our tribes grazing across the border have a right to do so by Treaty without giving up their allegiance to us and without being required to pay any duty or tribute seems to have been lost sight of,' wrote Somaliland's Commissioner Swayne in 1905. He interpreted 'subject' as applying only to dispute settlements. ${ }^{24}$ This logic of 'tribal' Somalis undergirded jurisdictional practice in which Somaliland officials pressed Ethiopian authorities to enforce clan-based dispute resolution and recognize transborder Somalis' exemption from Ethiopian taxation. Well after the Klobukowski Treaty established extraterritorial jurisdiction in principle, Somaliland officials' strategy of

\footnotetext{
${ }^{24}$ FO 401/8, Enclosure 5 in No. 87.
} 


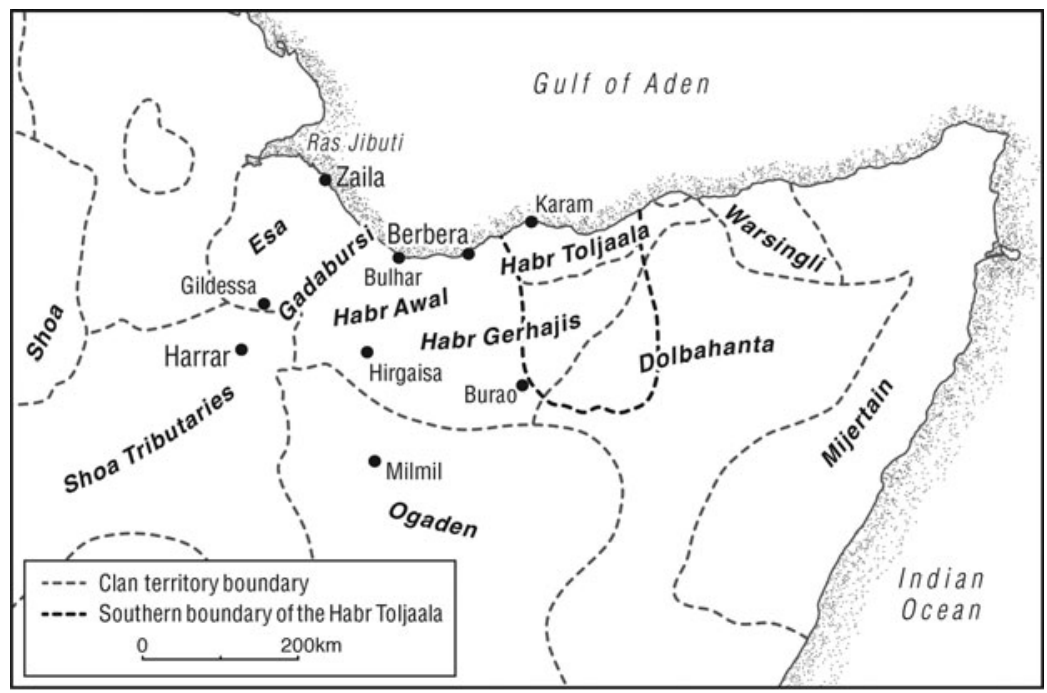

FIGURE 3 British administrators' estimation of clan territories in October 1891. Source: Author's replication of a sketch map from FO 403/155, Inclosure 2 in No. 60 (original spellings retained). Produced with permission from the UK National Archives.

borderlands governance sought to ground Somalis' subjecthood in clan territoriality. Struggles over Gadabursi subjecthood were connected to British interests in Isaqs' cross-border grazing and market access, and to emerging problems with clan territoriality as a logical basis for sovereignty.

Borderland struggles over cross-border subjecthood centred on the Isaq, Somaliland's most populous group. Britons' claims to the Isaq were in part based on the territorial framing that Isaqs' 'home wells' were in Somaliland while their 'grazing grounds' stretched into Ethiopia. By 1920, Isaq pastoralists' supposedly precolonial grazing lands were encroaching on those of Ethiopianprotected clans - a dynamic memorialized in the poetic line 'Doqonkii Ogaadeen ahaa, Doollo laga qaadaye' ('The Ogaden fools - Doollo was taken from them'). While colonial cartography must be read critically, British maps show Isaq territory expanding southwards and westwards over time. The Milmil wells, for example, fell squarely in Ogaden territory according to 1890s British cartography (Figure 3). A 1929 map, however, places Milmil within 'grazing areas of British tribes' (Figure 4). The map also displaces Ogaden claims by differentiating the space Ogaden were inhabiting 'at present' - which overlapped with claimed grazing areas of British tribes - from 'Ogaden limits' at Sasabaneh, well south of territories currently recognized as Ogaden heartland. This logic of precolonial 'tribal' territories established a basis for Somalis' British subjecthood that clearly did not apply to non-indigenous British subjects such as Indian traders who were also operating in regional towns.

It was also unclear, however, that the logic applied to Gadabursis. From the 1910 s to the 1920s, Britons debated theories of Gadabursi subjecthood and its 


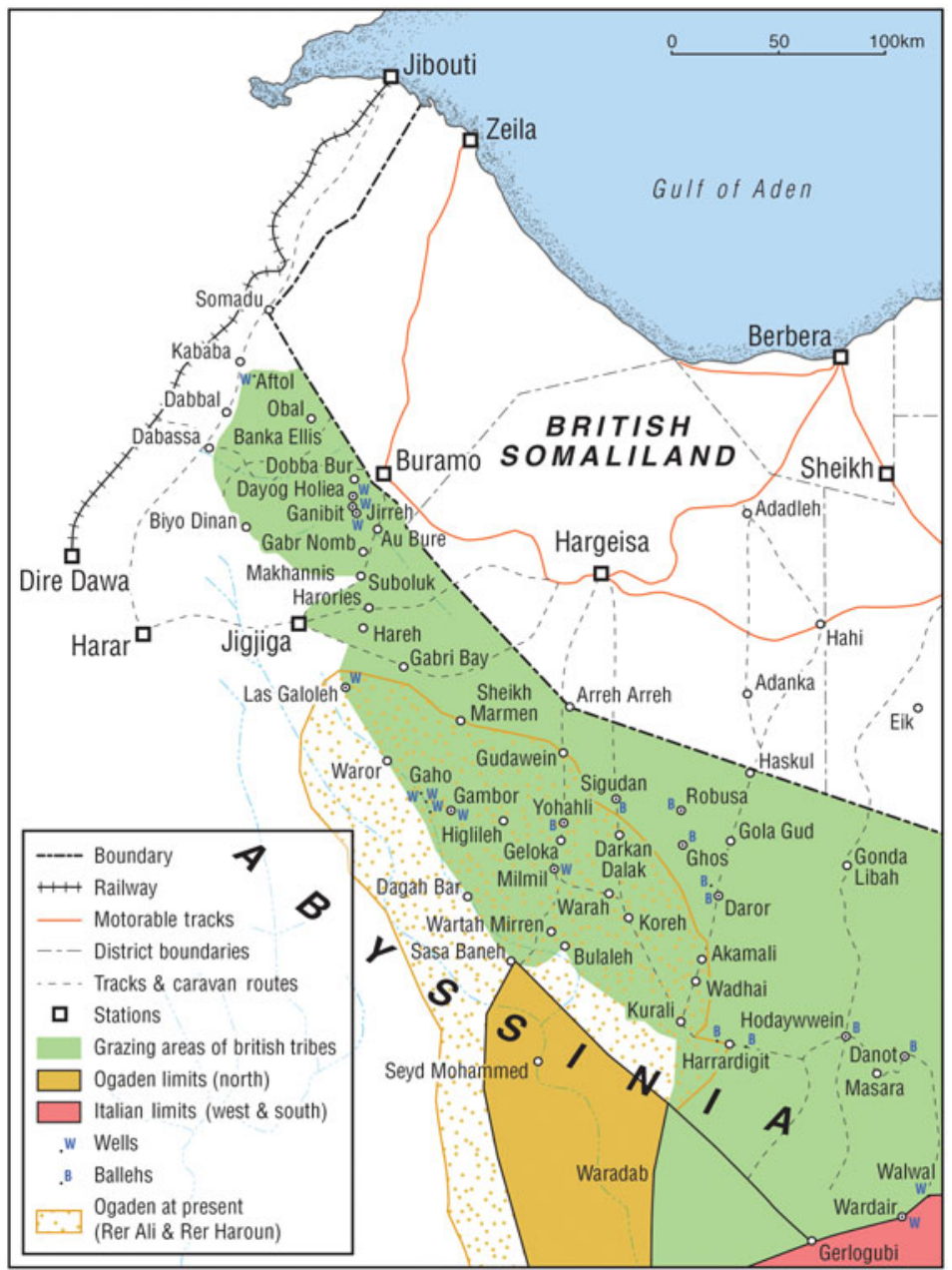

FIGURE 4 British Somaliland, showing grazing areas of British tribes in Abyssinian territory, in 1929. Source: Author's replication of a map from CO 535/90/6 (original spellings retained). Produced with permission from the UK National Archives.

relation to claims over extraterritorial Isaqs. 'At present the Gadabursi without exception are under the impression that they are British subjects,' Dodds wrote in June 1914, 'but they are mistaken.' He continued: 'The jilal [dry season] wells of certain of the Gadabursi sections are situated in Abyssinian territory, and the owners of these wells are, in my opinion, without any doubt Abyssinian subjects.' 25 Other administrators were reluctant to admit this claim. In 1919,

\footnotetext{
${ }^{25}$ FO 401/16, Enclosure 1 in No. 70.
} 
Somaliland's Commissioner Summers wrote that he was 'fully aware that the present attitude of His Majesty's Government is that all the Gadabursi are British protected subjects'. However, since Gadabursis' subjecthood could not be proven on the same grounds as Isaqs', he suggested, the Gadabursi could be a bargaining chip: if the Gadabursi were transferred to Ethiopia, the Abyssinians might 'actually refrain from levying taxes from other Somali tribes who are undisputedly British subjects'. ${ }^{26}$

Britons still disagreed over this issue by 1925 . By approaching the court case as 'a tribal matter' and mobilizing Gadabursi leaders to pay mag for the murder, Plowman avoided forcing a settlement on the basis of Gadabursis' subjecthood; rather, he worked to maintain the existing modus vivendi of clan-based indemnities and a blend of Ethiopian imperial law and regional practice. When the Somalis' case came before Tafari's High Court, Britons expected Tafari to affirm regional practice. 'Great was my horror and amazement,' wrote Bentinck regarding Tafari's judgment. 'I certainly had not anticipated the death sentence.'27

Bentinck's 'horror' was not at the death sentence. He had condemned a British Somali to death only that August. This inconsistency - that Britons would enforce the death penalty while preventing Ethiopians from doing so - formed a rationale for Tafari's judgment, handed down on 11 November:

The British consul said that, as the accused are Somalis, according to Somalis' law bloodmoney has to be paid, and they could not be condemned to death; that it was impossible to judge this matter according to Abyssinian law ... It seems that there is a mistake on this point, because two Somalis attended the court of the British consul-general at Addis Ababa on a charge of murder of one Somali, and one of them was condemned to death on the 4th August, 1925, and the other was sentenced to an imprisonment of one year. The said Somalis requested to be judged according to the law of their country, and paid blood-money, but the British consul-general put aside the law of the Somalis and judged them according to British law ... Therefore, I hereby condemn to death the three accused. ${ }^{28}$

Tafari's ruling astutely articulates Britons' position as one based on differences between Abyssinians and Somalis as groups with distinct customs. As shown above, from early in the case, Plowman had contrasted rights to revenge under 'Abyssinian law' with Somalis' custom of blood-money payment. ${ }^{29}$ The glossing of Ethiopian law as 'Abyssinian' exemplifies a recurrent slippage in British discourse between highland Abyssinian culture and efforts led by Abyssinian officials of Ethiopia (including Tafari) to consolidate a multi-ethnic state. Concurrent claims about Abyssinian cultural imposition on Ethiopia's southern territorial peripheries delegitimized Ethiopian rule over 'subject races' who had 'their own laws and customs' and therefore were not 'niggers in the accepted sense' ('niggers' meaning those 'intended by nature to act as serfs'). ${ }^{30}$

\footnotetext{
${ }^{26}$ Colonial Office (CO) 535/55/58941.

${ }^{27}$ FO $401 / 19$, No. 48.

${ }^{28} \mathrm{FO} 401 / 19$, Enclosure 9 in No. 48.

${ }^{29}$ FO 401/19, Enclosure 2 in No. 48.

${ }^{30} \mathrm{FO} 401 / 19$, Enclosure in No. 73.
} 
After suggesting that the British position sought to provincialize Ethiopian law, Tafari's ruling rejects this logic to affirm Ethiopian imperial law's equivalence to British law when it came to Somalis (an equivalence formalized in the 1897 Treaty). Even if daily practice enabled the coexistence of Somali custom and imperial law, for Tafari to recognize Somalis' exemption from imperial law in Ethiopia's High Court amidst Ethiopia's legal modernization was untenable. Tafari intended 'that the central/national legal system be understood as extending to all regions of the country equally' (Carmichael 2001: 68-9). In assuming his authority to judge other Africans native to Ethiopian territory, Tafari was operating according to one logical framework he shared with Britons: that of Somalis as natives whose customs were upheld for expediency but, when necessary, could be forcibly subordinated to imperial rule. Tafari's belief that Britons would recognize his authority over Africans was probably informed by a 1922 case in which Ethiopian authorities arrested a Sudanese British subject for murder. Britain's minister in Addis Ababa at the time did not assert extraterritorial jurisdiction 'partly on account of the man's undoubted guilt and partly because of his colour and race', since failure to secure this African's British protection 'would have weakened [Minister Russell's] ground in any future case where it might be necessary to secure the surrender of an Englishman or British Indian'. ${ }^{31}$ What Tafari evidently did not anticipate in 1925 is that extraterritorial jurisdiction over Somalis was now more deeply entwined with British interests in imperial prestige and sovereignty over merchant 'foreigners' (including British Indians) who were important to Britain's economic influence.

\section{The logic of extraterritorial 'nationals'}

Tafari's judgment provoked a dilemma for Bentinck. On the one hand, Bentinck understood the case as directly bearing on British authority over the Britishprotected Arab and Indian merchant class that had recently expanded in Ethiopia. On 21 July, Bentinck observed how inconvenient it was that 'unruly British Somalis ready to murder each other at the slightest provocation' claimed the same legal protections afforded to Indians and Arabs. ${ }^{32}$ British-protected foreign merchants, including large firms such as Mohamedally \& Company, appeared frequently in Harar's and Addis Ababa's Special Courts after 1922 (see cases in Scholler 1985). Most of these cases involved business disputes. Verdicts were evidently rarely enforced, leading Bentinck and others to worry increasingly about the effectiveness of extraterritorial jurisdiction in Ethiopia. On the day of the Somalis' Special Court trial (31 July), Bentinck complained to the Home Government: 'It is difficult to see in what manner His Majesty's Government can bring ... pressure to bear upon this country. Everyone knows that British troops will not march over the frontier to collect some millions of dollars for some Arabs and Indians.' 33 Again, at the time of this observation, Bentinck and others evidently expected Tafari to affirm eastern Ethiopian practice by ordering the Gadabursis to pay blood money to the murdered tax collectors'

\footnotetext{
${ }^{31}$ FO 401/20, No. 30 .

${ }^{32}$ FO $401 / 19$, No. 31 .

${ }^{33}$ FO 401/19, No. 32.
} 
families. On the other hand, after Tafari's November verdict, Bentinck recognized Home Government officials' likely reluctance to challenge Ethiopian sovereignty for the sake of a few Africans: '[I]t may be argued that the lives of three Somalis, who possibly committed a murder, are not worth it.'34

Tafari's verdict, at first surprising, created an opportunity to reframe the protection of Somalis from a tribal concern into an issue of broader imperial prestige and the protection of non-African merchants - and in a sense it forced Bentinck to do so. After validating the viewpoint of Somalis' lives as 'not worth' a challenge to Ethiopia's sovereignty, Bentinck conceptually grouped Somalis with 'foreigners' in an appeal to the Home Government: 'As, however, there are in this country thousands of British Somalis, Indians and Arabs, who look to His Majesty's Minister for their safety, I feel that weakness on our part would be criminal, and would entail far-reaching and serious consequences in the future.' ${ }^{35}$ With this logic Bentinck legitimized application of the Klobukowski Treaty, which mobilized Italian and French representatives to side with the British due to their own interests in the Treaty framework. Invoking the Treaty and thus rendering the case a multilateral affair also addressed the problem of bringing 'pressure to bear' on Ethiopia by threatening Tafari's international status.

Tafari argued to the Italian consul that the Treaty's intent was to protect Europeans, not 'Somalis and other coloured subjects'. Although Tafari reportedly withdrew his 'foolish' observation (Bentinck's words), ${ }^{36}$ it astutely reflects British inconsistencies. While invoking extraterritorial jurisdiction to protect Somalis in Ethiopia, British administrators were forcibly repatriating British Somalis from Britain and Egypt. ${ }^{37}$ Tafari reportedly sent the Italian consul a message asserting 'that it was his sovereign right to execute the Somalis, and that, if necessary, he would appeal to the League of Nations'. ${ }^{38}$ This threat, however, foregrounds the dilemma presented by Ethiopia's status in the League: a League intervention might have favoured Ethiopia. More likely, it would have invited the three powers to assert their influence against Ethiopia's League membership, which was already subject to scrutiny due to the special conditions attached.

In the end, Tafari had little choice but to acquiesce to European pressure. He accepted a blood-money payment equivalent to 500 camels for the five murdered soldiers. Britons continued to insist that this was not an admission of the Somalis' guilt. Talan Sharmarke, Ahmed Harwa and Doordei Samatar went free, sent to Somaliland under British protection in March 1926. ${ }^{39}$ In fulfilling Ethiopia's international obligations, Tafari was forced to subordinate his sovereign right to execute the Somalis to British assertions that Ethiopia's legal system did not apply to Gadabursis and other borderlands Somalis due at least in part to their racial identities. Somalis' status as British subjects was used to enforce the legal relevance of these identities. This corroborates and specifies Scholler's (1985: 50) argument that European-imposed restrictions on Ethiopian sovereignty

\footnotetext{
${ }^{34}$ FO $401 / 19$, No. 48.

${ }^{35}$ Ibid.

${ }^{36}$ FO 401/19, No. 52.

${ }^{37}$ See CO 535/60/39077.

${ }^{38}$ FO 401/19, No. 52.

${ }^{39}$ FO $401 / 20$, No. 32.
} 
were justified by 'discrepancies in race, religion, and civilization', with 'unacceptable political results'. Tafari was clearly reluctant to legitimize the idea that Somalis native to Ethiopia could be legally foreigners. After acquiescing to British demands, he registered his view that blood-money settlements for Somalis constituted a temporary measure of convenience, not a lasting rule. ${ }^{40}$

\section{Racialized sovereignty after the $1920 \mathrm{~s}$}

Evidently motivated by such cases, Tafari - crowned Emperor Haile Selassie in 1930 - entered the 1930s intent on dismantling European extraterritoriality. He was deterred by a convergence of international interests in upholding extraterritorial jurisdiction. ${ }^{41}$ Writing his autobiography while exiled in Britain during fascist Italy's occupation of Ethiopia (1935-41), Selassie discussed the 'grave accord affecting the honour of the country', 'the yoke of this treaty with which Ethiopia had been burdened', and 'in particular the judicial matters' that were 'extremely irksome to us' (Sellassie 1999: 67, 37, 94).

Racializations of Ethiopian sovereignty continued to justify European intervention. When Italians invaded Ethiopia in 1935, they legitimated their aggression before the League of Nations by alleging Ethiopia's barbarity, the continuance of slavery, and Amhara colonialism over other African groups (Parfitt 2011: 859). In a memorandum, Italian officials described the 'legal absurdity' involved in appeals from the Special Court to the Emperor's Tribunal (which Tafari's High Court became with his coronation as emperor), where cases were judged under 'Abyssinian law'. ${ }^{42}$ Parfitt (ibid.: 860) suggests that the British and French articulated similar rationales; their refusal to recognize League sanctions imposed on Italy reflected the continuation of 'a supposedly pre-League system according to which "sovereign" and "African" were mutually exclusive terms'.

When Britain restored Selassie to Ethiopia's throne in 1941, Somali-inhabited eastern Ethiopia was maintained under British Military Administration (BMA), which was in place from 1944 to 1954, although the Ethiopian government formally retained sovereignty over its territory as defined in 1897. A new Imperial High Court was established in 1942 under British tutelage, replacing the Special Court with a system in which a British judge presided in cases involving foreigners. Even if this restored a facet of Ethiopia's juridical sovereignty by applying uniform laws, as Fanta (2016: 69) argues, in the eastern borderlands deployments of race continued to undermine Ethiopian territorial sovereignty. The Italian invasion had precluded a settlement of the Gadabursis' subjecthood, debates over

\footnotetext{
${ }^{40} \mathrm{FO} 401 / 20$, Enclosure 3 in No. 32.

${ }^{41}$ The US government joined European powers in warning Selassie against repudiating the Klobukowski Treaty. See correspondence on 'Proposed revision of basic treaty governing Ethiopian relations with foreign powers', Papers Relating to the Foreign Relations of the United States, 1931, Volume II, pp. 251-69 at <https:/history.state.gov/historicaldocuments/ frus1931v02/ch15>, accessed 18 May 2020.

${ }^{42}$ United Nations Geneva Archives, C.340.M.171.1935.VII. 'Memorandum by the Italian government on the situation in Ethiopia', p. 13 at <https://biblio-archive.unog.ch/Dateien/ CouncilMSD/C-340-M-171-1935-VII_EN.pdf>, accessed 18 May 2020.
} 
which continued after the 1925 case. ${ }^{43}$ Under the subsequent BMA, British discourse shifted from assertions of Somalis' clan-based legal status towards foregrounding racial arguments that Somalis were properly subordinate to whites, but not to Abyssinians: '[D]uring the recent negotiations Ethiopians have been more or less told that we do not consider them competent to administer the outlying parts of their Empire and certainly unfit to rule Somalis. ${ }^{44}$

In connection with emerging anti-colonial nationalisms elsewhere, Somalis' assumed differences from 'Ethiopians' took on new valence in the 1940s. 'The Somali nation' appeared for the first time in British government maps, a vision subsuming clan-based territoriality in Ethiopia within a new supra-clan territoriality (Figure 5). The genealogy of Somali nationalism in this period, the role of groups such as the Somali Youth League, debates on Somali subjecthood, and the Bevin Plan to unite Somalis into one national jurisdiction lie beyond this article's scope (but see Barnes 2007; Geshekter 1985; Matshanda 2019). The point here is that, whatever logics of identity pre-existed imperialism or emerged during decolonization, imperial frameworks for enacting Somalis' political status and 'nationality' by the 1930s were already delimited by the two logics that converged in the 1925 murder trial. The framing of Somalis as 'natives' with autonomy and territorial authority (however limited) delegitimized Ethiopian sovereignty as a foreign imposition in the Somali-inhabited borderlands. At the same time, Ethiopia's formal territorial sovereignty was upheld while 'British Somalis' were legally rendered 'foreigners' exempt from Ethiopian prosecution. The contradictions between these two racializing logics set new parameters for ensuing struggles over whether Ethiopia could legitimately govern Somalis, and whether Somalis could become Ethiopian.

\section{Conclusion: Ethiopian sovereignty and territoriality}

I have argued that Britons' and Somalis' assertions about Ethiopian law's inapplicability to (some) Somalis during the 1925 trial conjoined two racialized logics delimiting the application of extraterritorial jurisdiction in eastern Ethiopia. The first - the logic of Somalis' nativeness to Ethiopian territory was recognized in Ethiopian legal practice through tolerance of Islamic law and existing dispute-resolution mechanisms alongside imperial law. In their defence of British Somalis during the 1925 Special Court case, Britons (mis)recognized this practice of legal pluralism in their assertion that Ethiopian law - ethnicized as 'Abyssinian' - did not apply to Somalis. This logic was incompatible with Ras Tafari's efforts to assert Ethiopia's territorial and international sovereignty, and he rejected it by sentencing the Somalis to death. In order to enforce their position and exempt their putative Somali subjects from Ethiopian prosecution, Britons then invoked the Klobukowski Treaty's provisions on formal extraterritorial jurisdiction. I have suggested that up until Tafari's verdict, neither British nor Ethiopian authorities appeared certain whether the Klobukowski Treaty applied to Gadabursi Somalis (or to Somalis, or perhaps to Africans). Its mobilization

\footnotetext{
${ }^{43}$ See FO 401/28, Enclosure 3 in No. 84.

${ }^{44}$ War Office (WO) 230/63, p. 5.
} 


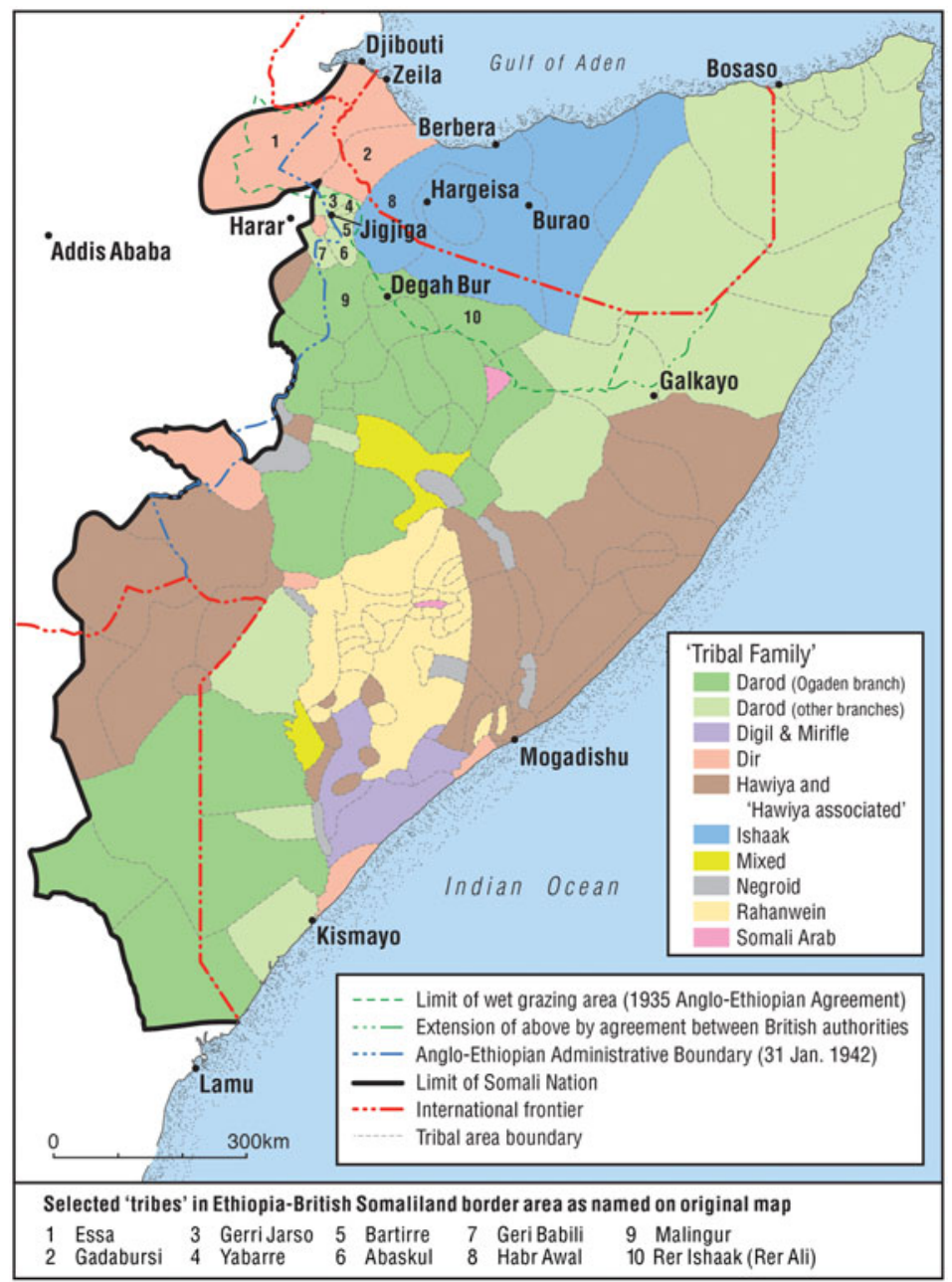

FIGURE 5 Tribal map of Somalia and British Somaliland, 1 January 1945. Source: Author's replication of map E51(117), Bodleian Libraries, University of Oxford. Coloured by 'number indicating stock' in original map. Produced with permission from Bodleian Libraries.

rendered the Somali defendants legally equivalent to 'foreign' British subjects such as Indians and Arabs, contradicting the logic of the 1897 Treaty that (in Britons' framing) exempted transborder Somalis from Ethiopian law based on their status as 'natives' with precolonial customs and territoriality. This is not to say that in lieu of British activity, Somalis would have been (or wanted to be) fully incorporated as Ethiopian citizens, but that the conjuncture of these two racializing logics precluded possibilities in that direction.

The analysis builds on a 'borders as resources' framework demonstrating how Somalis found room for agency amidst Ethiopian and European competition for 
empire (Barnes 2010; Cassanelli 2010), but connects elements of this agency to globalizing logics and legal frameworks regarding race, nationality and sovereignty. Taken together, the logics of Somalis' 'native' cross-border territoriality and their legal equivalence to 'foreign' British subjects worked for decades to generate opportunities for British Somalis' cross-border mobility and trade. However, by the 1960s, their history of avoiding Ethiopian rule and taxation tended to mark borderlands Somalis as debatable citizens and disloyal contrabandists. This dynamic had parallels in Kenya, where Somali claims to Asiatic status were revoked amidst the shift towards independence, but shaped identities in ways that legitimized Somalis' persistent state-enforced marginalization - in which, as in colonial times, some clan leaders participated in order to advance their own interests (Lochery 2012; Weitzberg 2017).

The effects of the 1925 case, however, were not localized to the borderlands. I have sought to foreground how applications of extraterritorial jurisdiction in the Ethiopia-British Somaliland borderlands both emerged from racialized political structures and tended to re-inscribe Ethiopia's subordinate international status. In their quest for international recognition, Ethiopian elites had been forced well before 1925 to assent to Eurocentric logics maintaining the African empire's subordination. International recognition, even as a subordinate power, had advanced Ethiopian control over other Africans, including Somalis. Perhaps Tafari would have been content with extraterritoriality applied to nonAfrican 'foreigners' during his early efforts to consolidate rule. In any case, he ultimately had to acquiesce to Britons' and Somalis' challenge to Ethiopia's territorial authority: in the 1925 case, Ethiopia's international status as a formally sovereign empire came at the price of disrupting Ethiopian rule over Somalis.

\section{Acknowledgements}

I thank Axmed 'Dowlo' Cabdi Haybe, Peter D. Little, Clifton Crais, David Nugent, Kristin Phillips, Donald Donham, and three anonymous reviewers for their helpful comments on earlier versions of this article. Research for this article was supported by the National Science Foundation (Award No. 1658234) and the Wenner-Gren Foundation for Anthropological Research (Award No. 9478).

\section{References}

Barnes, C. (2000) 'The Ethiopian state and its Somali periphery circa 1888-1948'. $\mathrm{PhD}$ thesis, Trinity College, University of Cambridge.

Barnes, C. (2007) 'The Somali Youth League, Ethiopian Somalis, and the Greater Somalia idea, c. 1946-48', Journal of Eastern African Studies 1 (2): 277-91.

Barnes, C. (2010) 'The Ethiopian-British Somaliland boundary' in D. Feyissa and M. V. Hoehne (eds), Borders and Borderlands as Resources in the Horn of Africa. Suffolk and Rochester NY: James Currey.

Burton, R. (1856) First Footsteps in East Africa: or, an exploration of Harar. London: Longman, Brown, Green and Longmans.

Carmichael, T. (2001) 'Approaching Ethiopian history: Addis Abäba and local governance in Harär, c. 1900 to 1950'. PhD thesis, Michigan State University. 
Cassanelli, L. (2010) 'The opportunistic economics of the Kenya-Somali borderland in historical perspective' in D. Feyissa and M. V. Hoehne (eds), Borders and Borderlands as Resources in the Horn of Africa. Suffolk and Rochester NY: James Currey.

Donham, D. (1986) 'Old Abyssinia and the new Ethiopian Empire: themes in social history' in D. Donham and W. James (eds), The Southern Marches of Imperial Ethiopia. Cambridge: Cambridge University Press.

Drake-Brockman, R. E. (1912) British Somaliland. London: Hurst \& Blackett.

Edwards, J. R. (1984) “"... And the king shall judge”: extraterritoriality in Ethiopia, 1908-1936' in S. Rubenson (ed.), Proceedings of the 7th International Conference of Ethiopian Studies, University of Lund, 26-29 April 1982. Addis Ababa: Institute of Ethiopian Studies.

Eshete, T. (1994) 'Towards a history of the incorporation of the Ogaden: 18871935', Journal of Ethiopian Studies 27 (2): 69-87.

Fanta, E. B. (2016) 'The British on the Ethiopian bench: 1942-1944', Northeast African Studies 16 (2): 67-96.

Feyissa, H. G. (2016) 'European extraterritoriality in semicolonial Ethiopia', Melbourne Journal of International Law 17: 107-34.

Frankel, S. H. (1938) Capital Investment in Africa: its course and effects. London: Oxford University Press.

Galaal, M. M. (2017) Jalleeco: taariikhdii dadka iyo deegaanka Soomaalida Itoobiya. Jigjiga: Kali Publishers.

Garretson, P. (1979) 'The naggadras, trade, and selected towns in nineteenth and early twentieth century Ethiopia', International Journal of African Historical Studies 12 (3): 416-39.

Geshekter, C. (1985) 'Anti-colonialism and class formation: the eastern Horn of Africa before 1950', International Journal of African Historical Studies 18 (1): $1-32$.

Hall, S. (1980) 'Race, articulation and societies structured in dominance' in UNESCO, Sociological Theories: race and colonialism. Paris: United Nations Educational Scientific and Cultural Organization (UNESCO).

Haybe, A. C. (2017) Qamaan Bulxan: taariikh iyo maansooyin. Jigjiga: Jigjiga University Press.

Hertslet, E. (1967) The Map of Africa by Treaty: Volume II, 3rd edition. London: Routledge.

Kapteijns, L. (2010) 'I. M. Lewis and Somali clanship: a critique', Northeast African Studies 11 (1): 1-23.

Keefer, E. (1981) 'Great Britain, France, and the Ethiopian Tripartite Treaty of 1906', Albion: A Quarterly Journal Concerned with British Studies 13 (4): 364-80.

Kelly, J. and M. Kaplan (2001) Represented Communities: Fiji and world decolonization. Chicago IL and London: University of Chicago Press.

Lochery, E. (2012) 'Rendering difference visible: the Kenyan state and its Somali citizens', African Affairs 111 (445): 615-39.

MacArthur, J. (2016) Cartography and the Political Imagination: mapping community in colonial Kenya. Athens $\mathrm{OH}$ : Ohio University Press.

Mamdani, M. (1996) Citizen and Subject: contemporary Africa and the legacy of late colonialism. Princeton NJ and Woodstock: Princeton University Press.

Marcus, H. G. (1971) 'The black men who turned white: European attitudes towards Ethiopians, 1850-1900', Archiv Orientální 39: 155-66. 
Marzagora, S. (2017) 'History in twentieth-century Ethiopia: the "great tradition" and the counter-histories of national failure', Journal of African History 58 (3): 425-44.

Matshanda, N. T. (2019) 'Constructing citizens and subjects in eastern Ethiopia: identity formation during the British Military Administration', Journal of Eastern African Studies 13 (4): 661-77.

Mills, C. W. (1999) The Racial Contract. Ithaca NY and London: Cornell University Press.

Parfitt, R. (2011) 'Empire des nègres blancs: the hybridity of international personality and the Abyssinia crisis of 1935-36', Leiden Journal of International Law 24: 849-72.

Pierre, J. (2013) The Predicament of Blackness: postcolonial Ghana and the politics of race. Chicago IL and London: University of Chicago Press.

Samatar, A. I. (1989) The State and Rural Transformation in Northern Somalia, 1884-1986. Madison WI and London: University of Wisconsin Press.

Scholler, H. (1985) The Special Court of Ethiopia, 1920-1935. Stuttgart: Franz Steiner Verlag.

Sellassie, H. (1999) My Life and Ethiopia's Progress, 1892-1937: Volume 1. Translated by E. Ullendorft. Barbados and Chicago IL: Research Associates School Times.

Sheik-'Abdi, A. (1993) Divine Madness: Mohammed 'Abdulle Hassan (18561920). London and New York NY: Zed Books.

Tekle-Mariam, T. (2006) Autobiography (My Life History). Addis Ababa: Addis Ababa University Press.

Turton, E. R. (1974) 'The Isaq Somali diaspora and poll-tax agitation in Kenya, 1936-41', African Affairs 73 (292): 325-46.

Weitzberg, K. (2017) We Do Not Have Borders: Greater Somalia and the predicaments of belonging in Kenya. Athens OH: Ohio University Press.

\begin{abstract}
This article argues that the politics of extraterritorial jurisdiction in the 1920s reshaped relations between ethnicity and territorial sovereignty in Ethiopia's eastern borderlands. A 1925 criminal trial involving Gadabursi Somalis began as what Britons deemed a 'tribal matter' to be settled through customary means, but became a struggle for Ethiopia's regent, Ras Tafari, to assert Ethiopia's territorial authority and imperial sovereignty. British claims of extraterritorial jurisdiction over Somalis amidst 1920s global geopolitical shifts disrupted existing practices of governance in Ethiopia's eastern borderlands and created a dilemma for Ethiopian authorities. In order to uphold international obligations, Ethiopian officials effectively had to revoke their sovereignty over some Somalis indigenous to Ethiopia. Yet Britons' practical application of extraterritoriality to Somalis was predicated on assumed racial differences between Somalis and highland Ethiopians ('Abyssinians'). Thus, Ethiopia's recognition of British extraterritorial jurisdiction would lend legitimacy to claims exempting Somalis from Ethiopian sovereignty due to differences in identity. The case reveals how assertions about race, nationality and 'tribal' identity articulated to subordinate Ethiopian rule to British interests and, in the longer term, to delegitimize Ethiopian governance over Somalis.
\end{abstract}




\section{Résumé}

Cet article soutient que la politique de juridiction extraterritoriale menée dans les années 1920 a refaçonné les relations entre ethnicité et souveraineté territoriale dans les régions frontalières de l'est de l'Éthiopie. En 1925, un procès pénal impliquant des Somalis gadabursi était au départ ce que les Britanniques jugeaient être une « affaire tribale » qui devait se régler de manière coutumière, mais a fini par devenir pour Ras Tafari, le régent d'Ethiopie, une lutte pour affirmer l'autorité territoriale et la souveraineté impériale de l'Éthiopie. Les revendications britanniques de juridiction extraterritoriale sur les Somalis, dans le contexte des mutations géopolitiques mondiales des années 1920, perturbaient les pratiques de gouvernance qui existaient alors dans les régions frontalières de l'Est de l'Éthiopie, et créaient un dilemme pour les autorités éthiopiennes. Afin de respecter leurs obligations internationales, les responsables éthiopiens ont dû, de fait, renoncer à leur souveraineté sur certains Somalis indigènes d'Éthiopie. Cependant, l'extraterritorialité appliquée dans la pratique par les Britanniques aux Somalis reposait sur des différences raciales présumées entre Somalis et Éthiopiens des hautes terres (« Abyssiniens »). Ainsi, la reconnaissance par l'Éthiopie de la juridiction extraterritoriale britannique revenait à prêter une légitimité aux revendications visant à exempter les Somalis de la souveraineté éthiopienne en raison de différences d'identité. Ce cas révèle comment des assertions de race, de nationalité et d'identité « tribale » s'exprimaient pour subordonner le régime éthiopien aux intérêts britanniques et, à plus long terme, pour délégitimer la gouvernance éthiopienne exercée sur les Somalis. 